\title{
Asteraceae in a megadiverse flora: Results from the Flora of Brazil 2020
}

\author{
Carolina M. Siniscalchi, '(i) Benoit Loeuille ${ }^{2}$ (D) \& Nádia Roque ${ }^{3}$ (D)
}

\begin{abstract}
' Department of Biological Sciences, Mississippi State University, 295 Lee Blvd, Mississippi State, MS 39762, United States; carol.siniscalchi@gmail.com 2 Departamento de Botânica, Centro de Biociências, Universidade Federal de Pernambuco, Avenida Professor Moraes Rego, I235, Recife, Pernambuco, 50670-90।, Brazil; benoit.loeuille@gmail.com

${ }^{3}$ Instituto de Biologia, Universidade Federal da Bahia, Rua Barão de Geremoabo s. n., Campus Universitário de Ondina, Salvador, Bahia, 40 I7I -970, Brazil; nadiaroque@gmail.com
\end{abstract}

DOI: http://dx.doi.org/l0.53875/capitulum.01.1.06

Keywords: Biodiversity, South America, Global Strategy for Plant Conservation, collaborative effort.

The Global Strategy for Plant Conservation (GSPC), established in 2002 by the Conference of Parties, set up a number of targets to decrease the loss of plant diversity, lessen poverty and support sustainable development. The goals of GSPC Target I aim to warrant that plant diversity is globally wellunderstood by 2020. To achieve these goals, Brazil committed to the Flora of Brazil 2020 project (20 I 62020) (http://floradobrasil.jbrj.gov.br), coordinated by the Jardim Botânico do Rio de Janeiro (JBRJ). It consists of a list of all Brazilian plants, algae and fungi, with short morphological descriptions, identification keys and geographic distributions of all taxa (Figure I). The flora system also links to a virtual herbarium containing high-resolution images of type collections from large European collections and specimens from several Brazilian herbaria, which can be annotated by experts working on the floristic treatment (BFG 20I5, 20I8). Sixtysix synantherologists collaboratively prepared the floristic treatment for Asteraceae, under the supervision of Nádia Roque and Jimi N. Nakajima (Roque et al. 2021).

The results from this effort bring into light the importance of Asteraceae in the context of one the world's richest floras (Roque et al. 20 I7). The family is the third most diverse in Brazil, being represented by 27 tribes, 326 genera ( 85 monospecific) and
2,205 species (95\% native) and 1362 are endemic to Brazil. Compared to the first two richest families, Fabaceae and Orchidaceae, Asteraceae has the largest number of endemic genera (7I). The tribes Eupatorieae Cass. (6II spp.), Vernonieae Cass. (485 spp.), Astereae Cass. (245 spp.) and Heliantheae Cass. (220 spp.) are the richest in number of species, representing approximately $71 \%$ of the family diversity.

The Brazilian territory is covered by six phytogeographical domains: Amazon forest, Atlantic forest, Cerrado, Caatinga, Pantanal and Pampa. Asteraceae is the most species-rich family in the Cerrado and Pampas and is within the top five species-rich family in all domains except the Amazon (BFG 20I5). The Cerrado and Atlantic Forest, which are both considered biodiversity hotspots (Myers et al. 2000), present the highest absolute number of species of Asteraceae (Figure 2).

The Cerrado, or the central Brazilian savanna, presents two vegetation strata: a medium to low stature arboreal layer, consisted of scattered, fireresistant trees with contorted trunks and branches, usually with a thick and corky bark, and a herbaceous layer, where Asteraceae predominates along with several species of grasses. Asteraceae is represented by 191 genera and 1,246 species in this domain, 


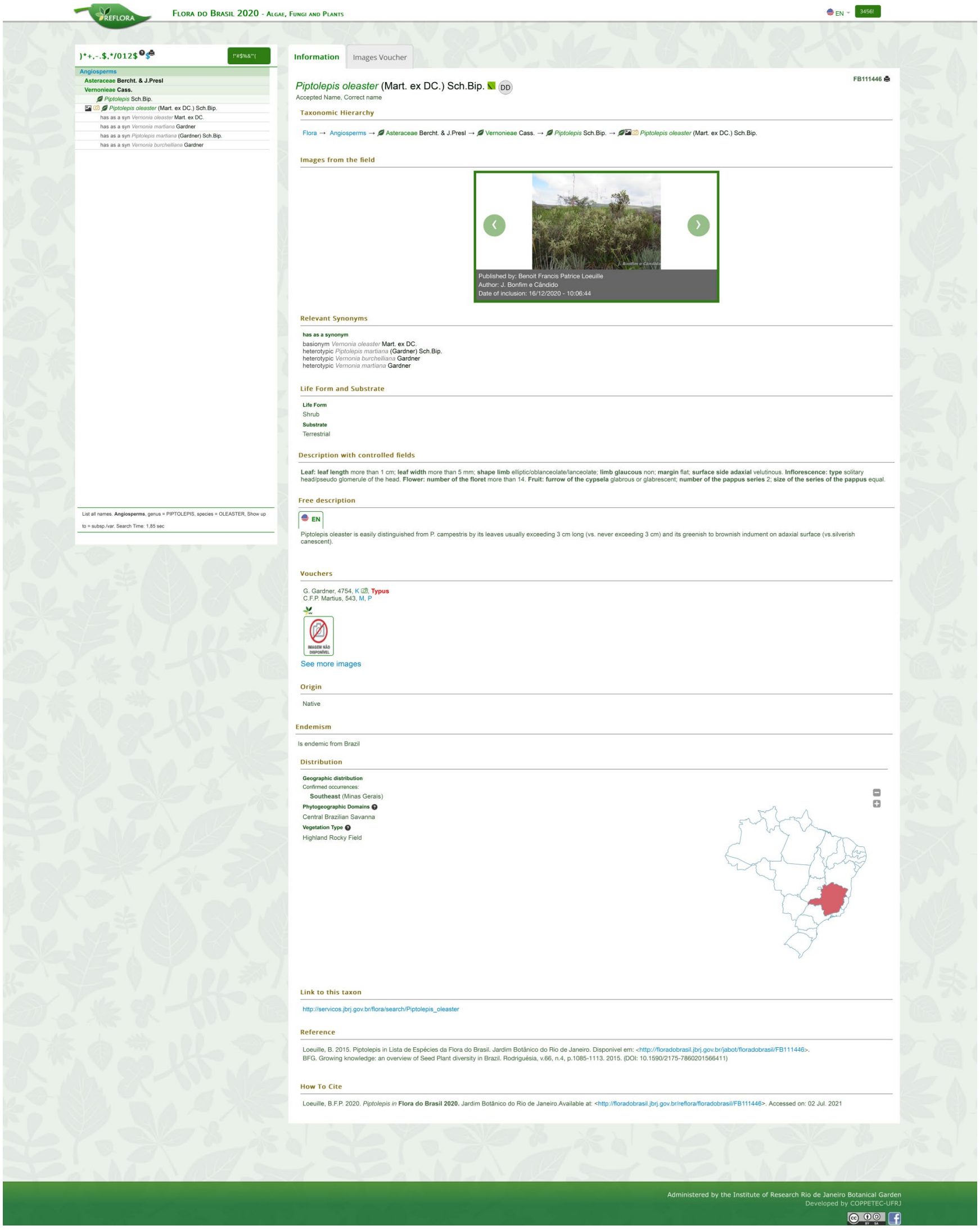

Figure I. Flora of Brazil web portal. Sample page of the type of information available at the species level. 


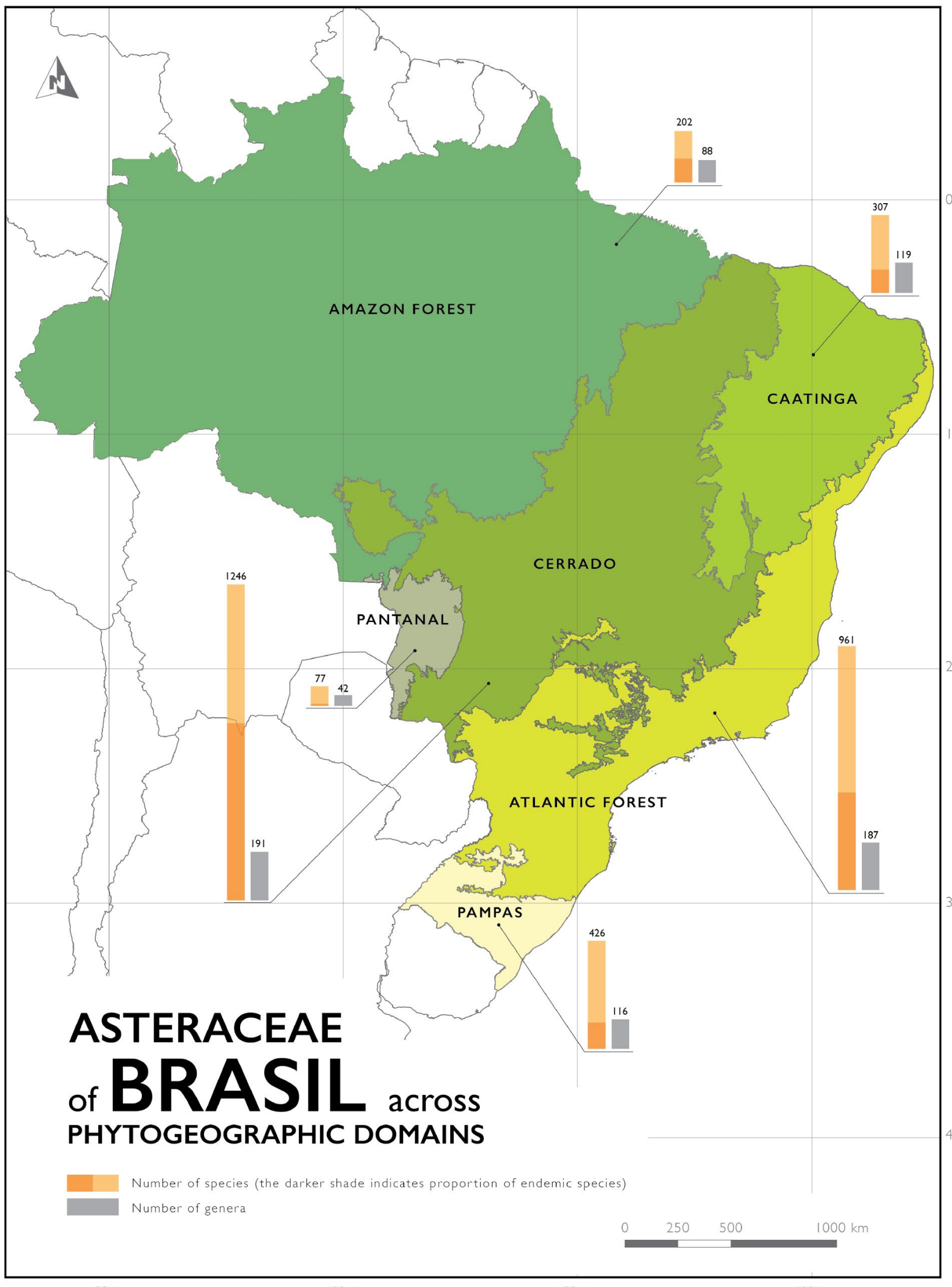

Figure 2. Asteraceae diversity and endemism across phytogeographic domains. 


\section{Wunderlichia}

Wunderlichia Riedel ex Benth. is a genus endemic from Brazil that comprises five species, three of which are deciduous trees up to 6 meters tall. The species shown here, Wunderlichia mirabilis Riedel ex Baker is locally known as pau-com-flor ("stick with flower").

Wunderlichia mirabilis in Licínio de Almeida, Bahia, Brazil. Photo by Nadia Roque
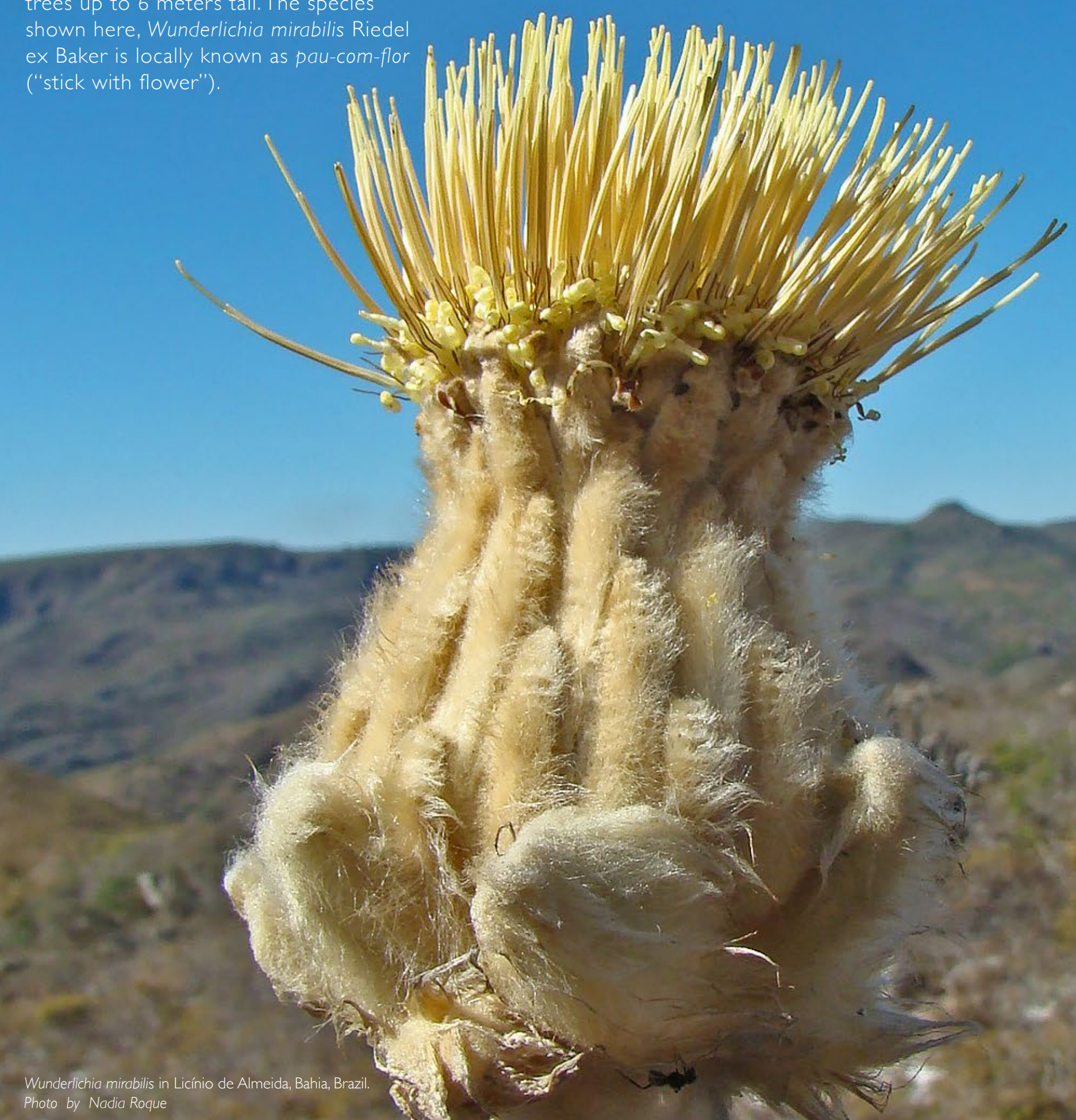

Nuing

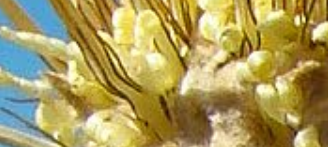



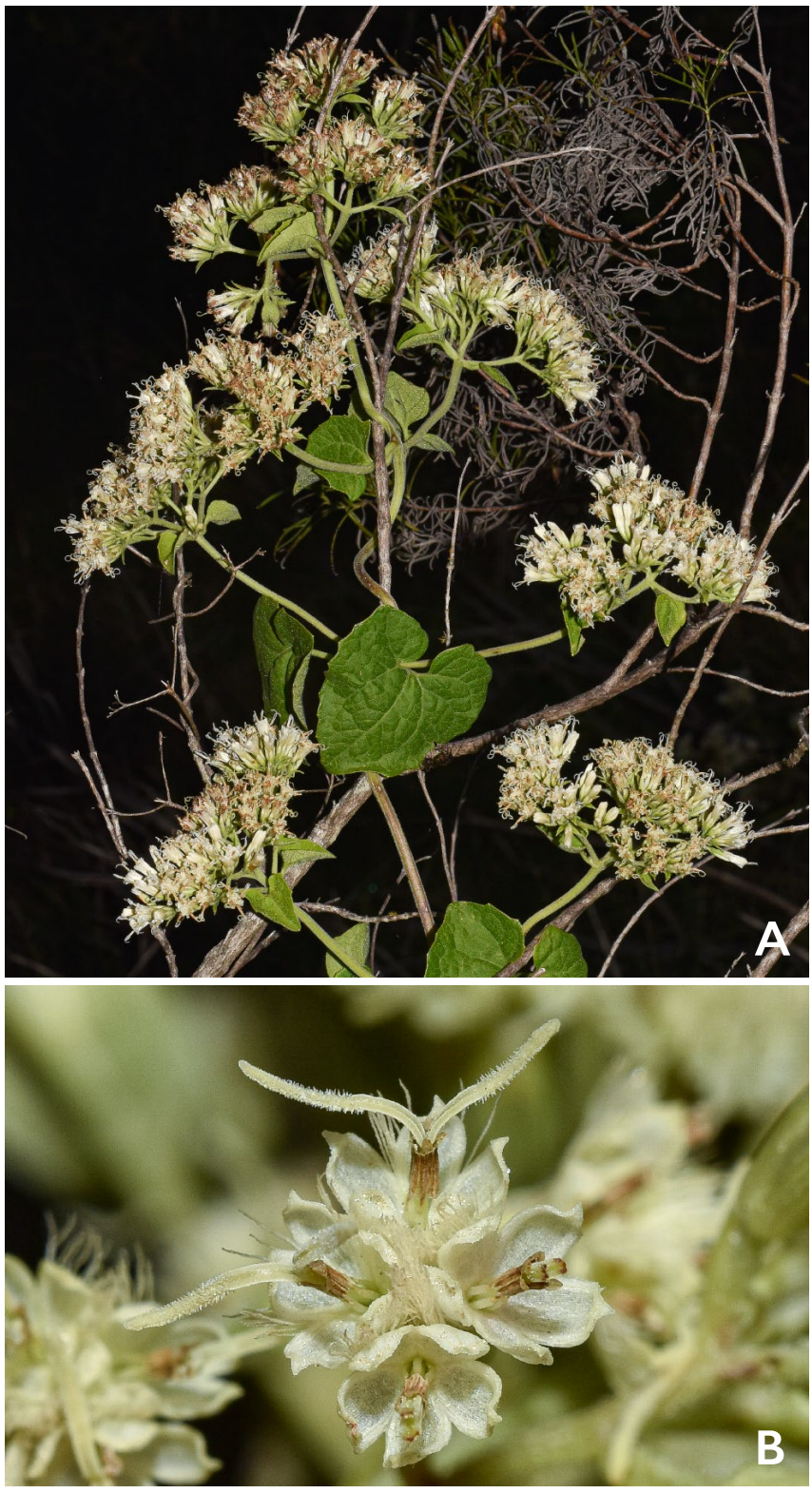

Figure 3. Mikania Willd., the largest genus (199 spp.) in the Brazilian flora. A. Mikania cordifolia (L.f.) Willd., showing typical climbing habit for the vast majority of the species in the genus. B. Close up of head of Mikania anethifolia (DC.) Matzenb., showing one of Mikania's defining traits, i.e. 4-floret heads. Photos: M. Bonifacino.

695 of which endemic (Figure 2). Some of the more diverse genera are Aldama LaLLave \& Lex. (33 spp. - $92 \%$ of the genus species), Eremanthus Less. ( 19 spp. - 86\%), Lessingianthus H.Rob. (98 spp. - 85\%), Calea L. (68 spp. - 80\%), Aspilia Thouars (52 spp. 80\%; Figure 4E), Chromolaena DC. (45 spp. - 65\%), Lepidaploa (Cass.) Cass. (34 spp. - 61\%). Soaresia Sch.Bip. (one sp.), Pseudostifftia H.Rob. (one sp.; Figure 4C), and Staurochlamys Baker (one sp.) are examples of monotypic endemic genera.
Lychnocephalus Mart. ex DC. an endemic genus with four species (Figure 4D) and Trichogonia Gardner, I 4 species from 20 are endemic to Brazil (Figure 4F), are mainly distribuded in Cerrado domain.

The Atlantic forest is one of the world's richest biomes and yet notoriously endangered and understudied. This rainforest spans the whole coastal area of the country and presents different physiognomies related to latitudinal and elevation changes. Asteraceae is represented by 187 genera and 961 species in this domain, 383 of them endemic (Figure 2). Genera with climbing habits are well-represented in this predominantly arboreal domain, such as Mikania Willd. (I23 spp.; Figure 3) and Piptocarpha R.Br. (24 spp.). The most numerous genus is Baccharis L. (I 34 spp.), and other representative genera are Senecio (47 spp.) and Stevia Cav. (I 7 spp.).

The Caatinga is a mosaic of seasonally dry, deciduous forests occurring in the semi-arid portion of the Northeast region. Due to the long dry season, the vegetation is characterized by a variety of xeromorphic plants, where families like Cactaceae, Bromeliaceae and Fabaceae are abundant. Asteraceae is represented by 119 genera and 307 species, of which 12 genera and 92 species are endemic (Figure 2). Many small or monotypic genera are restricted to this domain, such as Blanchetia DC., Caatinganthus H.Rob., Mattfeldanthus H.Rob. \& R.M.King and Piqueriella R.M.King \& H.Rob. The most species-rich genera are Mikania and Baccharis (23 spp. each) and Acritopappus Bercht. \& Presl ( 3 spp.).

The Amazon forest is the largest and most diverse of all tropical forests worldwide, being composed by an archipelago of distinct areas of endemism separated by the major rivers. From the six domains, the Amazon is where Asteraceae presents one of the lowest numbers of recorded species (88 genera/202 species), but 94 of them are endemic (Figure 2). These including five genera from Stiffitieae D. Don (Eurydochus Maguire \& Wurdack, one sp.; Glossarion Maguire, two spp.; Gongylolepis R.H.Schomb., one sp. and Neblinaea Maguire \& Wurdack, one sp.) and two genera from Wunderlichieae Panero \& V.A.Funk (Stenopadus S.F.Blake, two spp. and Stomatochaeta (S.F.Blake) Maguire \& Wurdack, one sp.). Due to the overall deficit of floristic studies in this domain and their usually stronger focus on arboreal species, it is likel $y$ that much of the Asteraceae diversity in the Amazon is still unknown to science. 

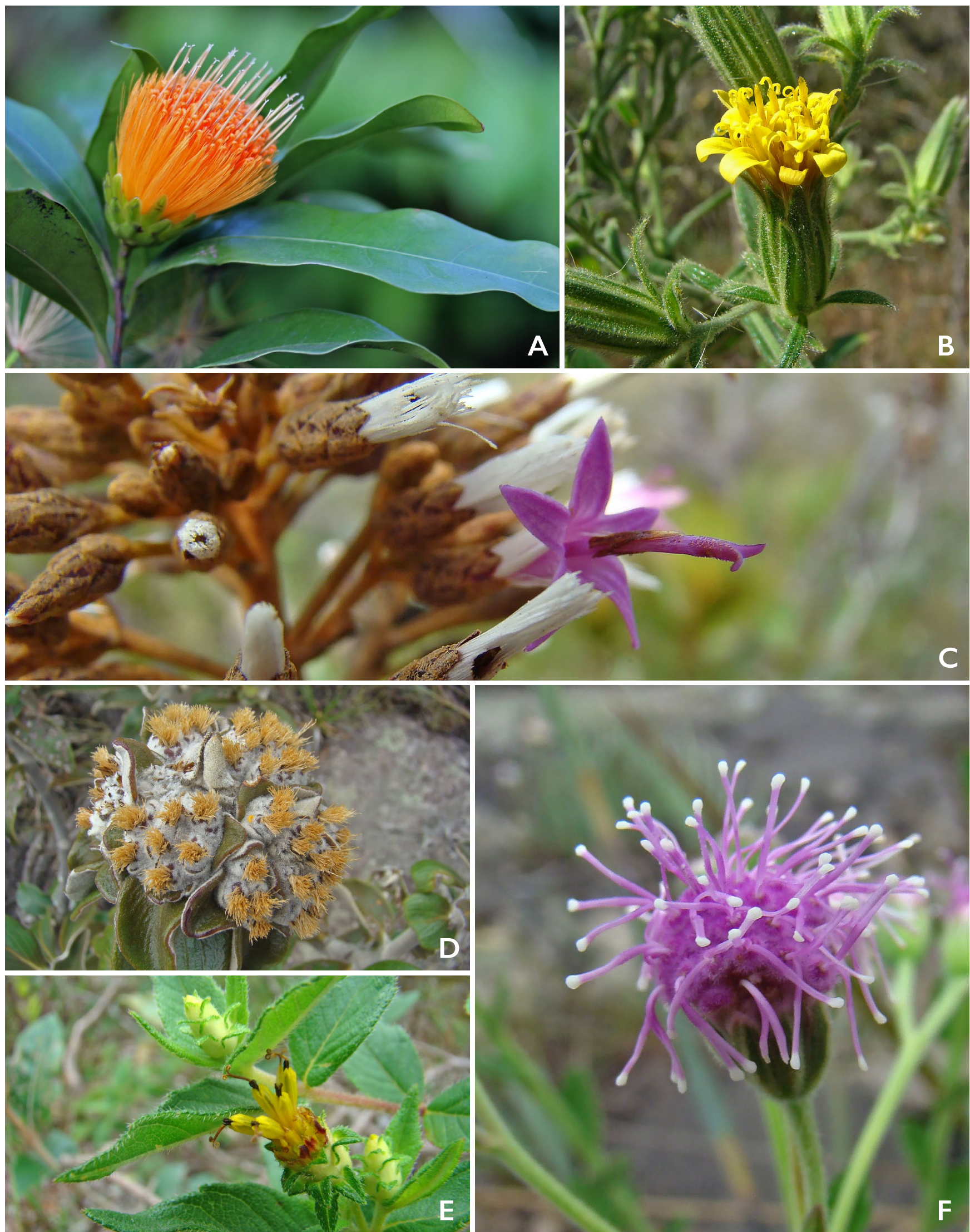

Figure 4. Asteraceae representatives from Brazil. A. Stifftia chrysantha J.C.Mikan. B. Trixis glutinosa D.Don. C. Pseudostifftia kingii H.Rob. D. Lychnocephalus tomentosus Mart. ex DC. E. Aspilia egleri J.U.Santos. F. Trichogonia villosa (Spreng.) Sch.Bip. ex Baker. Photos: A, C, L. Moura, B, D, F, N. Roque, E M. Alves. 


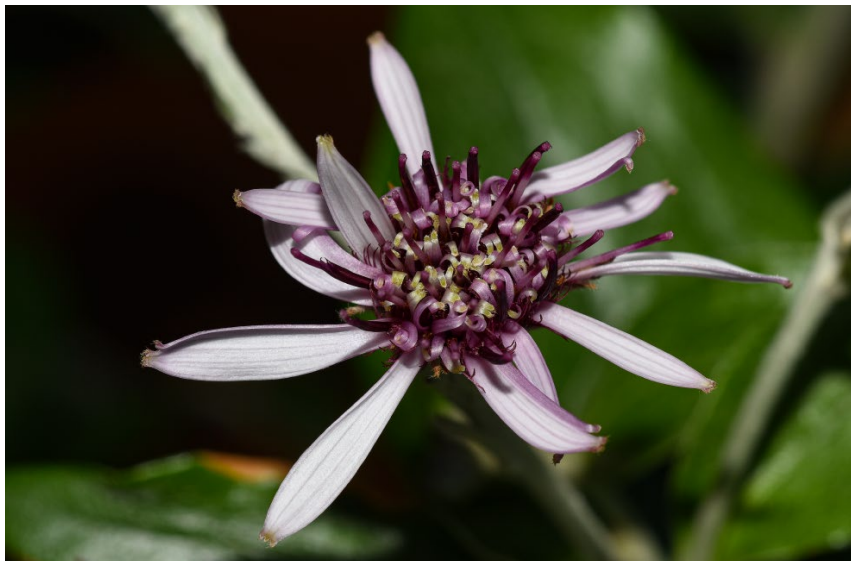

Figure 5. lanthopappus corymbosus (Less.) Roque \& D.J.N.Hind, restricted to the Pampas. Photo: M. Bonifacino.

In the Pampas, a domain restricted to the southernmost portion of the country, Asteraceae is represented by 116 genera and 426 species, with 24\% ( 103 spp.) of them being endemic to the Pampas (Figure 2). Some important genera are: Pterocaulon Elliott ( I spp. in Brazil, all of them ocurring in the Pampas), Hypochaeris L. (9 spp.), Gamochaeta Wedd. (I 5 spp.), Noticastrum DC. (7 spp.), Conyza Less. (I I spp.) and Achyrocline (Less.) DC. (I0 spp.).The tribe Astereae represents almost a third of all Asteraceae species in the Southern region of Brazil. Some genera restricted to this region are: Criscia Katinas, Grindelia Willd., Hysterionica Willd., lanthopappus Roque \& D.J.N.Hind, Microgyne Less., and Schlechtendalia Less.

The Pantanal domain is the one that presents the smallest diversity of Asteraceae. The family is represented by 42 genera and 77 species in this domain, with eight species endemic to Brazil (Figure 2). Aspilia, Dimerostemma Cass. and Calea species are some representative genera of Pantanal.

Due to this large collaborative effort, the completion of the Asteraceae treatment in Flora of Brazil 2020 was achieved at the end of 2020. The last comprehensive floristic treatment for the family in Brazil was Martius' Flora Brasiliensis, published at the end of the 19th century. This treatment offers a unique global picture of the current taxonomic knowledge of the family, besides showing poorly known taxa and geographic areas that need stronger collection efforts, giving us directions for future research. It is also a fantastic tool to aid identification of Asteraceae species or simply to discover the rich diversity of Brazilian Asteraceae.

\section{ACKNOWLEDGMENTS}

We thank all synantherologists that collaborated to conclude this huge project. We also thank Rafaela Campostrini Forzza and the Flora Project Steering Committee for logistic support and leading the Flora of Brazil project. NR thanks CNPq for the scholarship (PQ 307272/20 I9-2)

\section{LITERATURE CITED}

BFG - The Brazil Flora Group. 20I5. Growing knowledge: an overview of seed plant diversity in Brazil. Rodriguésia 66: |085-| | | 3. DOI: | 0.1590/2 |75-786020|5664| |.

BFG - The Brazil Flora Group. 2018. Brazilian Flora 2020: Innovation and collaboration to meet Target I of the Global Strategy for Plant Conservation (GSPC). Rodriguésia 69: 1513|527. DOI: |0.1590/2175-786020|869402.

Myers, N.,Mittermeier, R.A., Mittermeier, C.G., Fonseca, G.A.B. \& Kent, J. 2000. Biodiversity hotspots for conservation priorities. Nature 403: 853-858.

Roque, N., Teles, A.M. \& Nakajima, J.N. (eds.). 2017. A familia Asteraceae no Brasil: classificação e diversidade. Salvador: EDUFBA.

Roque, N., Nakajima, J., Heiden, G., Monge, M., Ritter, M.R., Loeuille, B.F.P., Christ, A.L., Rebouças, N.C., Castro, M.S., Saavedra, M.M., Teles, A.M., Gandara, A., Marques, D., Bringel Jr., J.B.A., Angulo, M.B., Santos, J.U.M.D., Souza-Buturi, F.O., Alves, M., Sancho, G., ReisSilva, G. A., Volet, D.P., Hattori, E.K.O., Plos, A., SimãoBianchini, R., Rivera, V.L., Magenta, M.A.G., Silva, G.H.L., Abreu, V.H.R., Grossi, M.A., Amorim, V.O., Schneider, A.A., Carneiro, C.R., Borges, R.A.X., Siniscalchi, C.M., Bueno, V.R., Via do Pico, G.M., Almeida, G.S.S., Freitas, F.S., Deble, L.P., Moreira, G.L., Contro, F.L., Gutiérrez, D.G., Souza-Souza, R.M.B., Viera Barreto, J.N., Soares, P.N., Quaresma, A.S., Picanço, W.L., Fernandes, F., Mondin, C.A., Salgado, V.G., Kilipper, J.T., Farco, G.E., Ribeiro, R.N., Walter, B.M.T., Lorencini, T.S., Fernandes, A.C., Silva, L.N., Barcelos, L.B., Barbosa, M.L., Bautista, H.P., Casas, J.C., Dematteis, M., Ferreira, S.C., Hiriart, F.D., Moraes, M.D. \& Semir, J. (in memoriam). 2020. Asteraceae in Flora do Brasil 2020. Jardim Botânico do Rio de Janeiro. http://floradobrasil.jbrj.gov.br/reflora/floradobrasil/ FB55 (accessed 26 May 2021) 